\title{
The Laticiferous System of Hevea brasiliensis and its Protective Function.
}

BY

\section{A. SHARPLES.}

F XPERIMENTAL work designed to test the suggestions put forward E to explain the significance of the rôle played by the laticiferous system of latex-bearing trees has seldom been attempted. Of the suggestions long standing, the one that latex exercised a protective function against fungus and insect attacks has received popular acceptance amongst the rubber-planting community of the Middle East. M. George Vernet brought forward evidence indicating that small boring-beetles, e.g. Xylehorus parvulus, Ptorelephia melaneura, could penetrate the bark of a healthy rubber tree without being killed by the latex, but the general opinion was stated by Pratt: ${ }^{1}$ 'In most cases of insect attack' (with special reference to shot-hole borer [Xyleborus parvulus]) ' on Hevea brasiliensis which have been personally observed it would appear that a fungus disease preceded the insect attack.' Thus it would appear that a healthy tree with a sound laticiferous system could not be penetrated by insects; the latter are only capable of penetrating into the wood when the laticiferous cells are killed previously by the fungus hyphae.

The method of tapping Hevea brasiliensis and the wound-response exhibited is universally known and needs no further description. Many methods of artificially stimulating this wound-response and so obtaining a correspondingly greater yield of latex have been suggested and tried on the plantations. One method, recently given much publicity and tried on a large scale, was suggested by Dr. Fickendy, late Director of Agriculture in Samoa. He applied for patent rights, and claimed an increase yield of 50 per cent.

His method consisted of scraping the bark over the proposed tapping area some time previous to the tapping. When the outer corky bark is gently scraped away with a blunt instrument, the cork-cambium (phellogen) is exposed as à green layer overlying the cortical cells. Fickendy's suggestion was to scrape away the corky cells, exposing the phellogen, but leaving the latter intact. The response to the stimulus of scraping should be a substantial increase in the yield of latex.

1 Pratt, H. C. : Repoit of Director of Agriculture, F.M.S., I9I 4.

[A nnals of Botany, Vol. XXXII. No. CXXVI. April, 1918.] 
One rubber estate in Malaya adopted Fickendy's methods and soon began to suffer from attacks by Xyleborus parvulus (shot-hole borer). When the attacked trees were inspected it appeared that the bark-scraping was the fundamental cause of the trouble. The explanation was unsatisfactory in the absence of experimental data, so an experiment was started to test the effect of bark-scraping upon rubber trees, with a view to elucidating whether such treatment makes the trees more liable to attack from fungi and insects. For the experiment 30 well-grown, 5 years old, untapped trees were taken. They were divided into five blocks, each containing six trees. The blocks were marked I A, I B, I C, $2 \mathrm{~A}$, and $2 \mathrm{~B}$. Block I C acted as control to Blocks I A and I B. The treated trees were scraped on $28 / 5 / \mathrm{I} 5$, over half their circumference, to a height of four feet from the ground. Care was taken that the laticiferous layer was unharmed, no latex exuding after the scraping.

Block I A. Scraped heavily, the green cork-cambium being removed. The scraped area was watered daily, with a hand-pump, for a few minutes.

Block I B. Trees scraped lightly, the green cork-cambium (phellogen) being left intact. Watered as I A.

Block I C. Unscraped, but water applied as I A and I B.

Block 2 A. Scraped as I A, but no water applied over scraped areas.

Block 2 B. Scraped as I B, but not watered.

Blocks I A, I B, and I C were treated with water daily in order to prevent a spell of dry weather interfering with the progress of the experiment. The results given below of the treatment are most interesting. A daily examination of the trees was made, the dates given below indicating the day upon which the attacked trees were first noticed.

Examined I/6/15. Block I A showed one tree badly attacked by boring beetles, the latex streaming down the bark. The remaining five trees in this block also showed attempts on the part of the insects to pierce the bark. None of the trees of the other blocks showed any sign of attack.

Examined $6 / 6 / 15$. One tree in Block $2 \mathrm{~A}$ very badly attacked by borers.

Examined II/6/15. One tree in Block 1 B attacked by borers; another tree in Block $2 \mathrm{~A}$ showed signs of a bursting of the bark, from which latex was exuding.

Examined 14/6/I5. A third tree in Block 2 A showed signs of the bark bursting, with exudation of latex.

Examined 30/6/15. One tree in Block $2 \mathrm{~A}$ shows cracks in bark with latex exuding.

From $28 / 5 / 15$ to $2 / 6 / 15$, there was no rain; from $2 / 6 / 15$, daily showers were the rule.

Thus, out of twenty-four treated trees, five were attacked as a result of the bark-scraping. Of these, four were heavily scraped and only one lightly 
scraped. The control trees in Block I C and the remaining untreated trees in the surrounding area were unaffected. The unscraped areas of the treated trees showed no sign of beetle attack.

The trees were affected in two different ways: One tree in Block I A, one in Block $\mathrm{I} B$, and one in Block $2 \mathrm{~A}$, suffered from a direct attack from boring beetles. The bark of the remaining two trees affected in Block $2 \mathrm{~A}$ were attacked by a fungus, which progressed rapidly in one case, killing the bark over a large area, but in the other only small areas of bark were attacked, and this tree now showed signs of recovery. The tree with cracks in the bark and latex exuding in Block $2 \mathrm{~B}$ was not affected further. A striking feature was the rapidity of the attack, borers being active on the first affected tree within four days.

The results show that removal of the outer corky layers increases the susceptibility of the trees to attack by fungi and insects. They show also that if the green cork-cambium is left intact the susceptibility to attack is less than it is when this layer is scraped away. This experiment indicates that the corky integument is the important protective layer against insect and fungus attacks and not the laticiferous layer. The activity of the borers on the trees in Block I A and $2 \mathrm{~A}$, within a week of scraping the bark caused exudation of the latex in streams down the scraped areas. Dozens of beetles were caught in the streaming latex, but this did not prevent others getting through the bark into the wood. It may be emphasized here, that the experimental plot is clear of timber, is fairly widely planted, $24 \mathrm{ft}$. by $\mathrm{I} 2 \mathrm{ft}$., and more or less isolated from the rest of the plantations, so that conditions are not favourable for the insects. The rapid nature of the attack prevents the assumption of a fungus preceding and killing the tissue in advance of the borers.

The results obtained confirm field observations. The years I9I $5^{-16}$ have been noteworthy for a very heavy wintering of the trees on the plantations during the months January, February, and March. The wintering period in both cases coincided with a spell of dry weather and numerous cases of leaf fires occurred, the thick carpet of leaves on the ground burning furiously. The trunks of the trees in the area through which the fires passed were scorched up to a height of ten feet, and borers were quickly at work on the scorched portions of the trees. In every case a copious exudation of latex was noticeable from the bore-holes, but this did not prevent the entry of the insects. One estate was visited four days after the fires had been put out, and the boring beetles were actively working on half a dozen trees not badly scorched and from which there was a good flow of latex beneath the scorched areas. The laticiferous system was obviously healthy at the time of the attack, but the flowing latex did not prevent the insects penetrating into the wood. If the outer corky, protective layers of Hevea brasiliensis are removed or injured the tree is liable to a direct attack from boring beetles. 
Heavy scraping of the bark, i. e. removal of the cork-cambium, exposes the outer old cortical cells. It is possible that in such tissues a corkcambial layer does not form very readily, so that the outer cortical cells are exposed to the atmosphere for a comparatively long period. If this coincides with a period of wet weather, the exposed cells become waterlogged and their activities interfered with. As a result, numerous ordinarily saprophytic fungi flourish on the exterior and grow inwards gradually, rotting the bark from the ontside. Undoubtedly this is the method of attack in cases where there is not a direct attack by borers. The same applies to trees scraped so as to leave the cork-forming cambium intact. Such trees are not so readily attacked, due to the active cork-cambium quickly cutting off cork cells to the outside, forming a new protective layer. This rapid formation of cork prevents water-logging of the cells, and the danger of attack is considerably lessened thereby. But if the cork-cambium cells by any chance become water-logged, their activities are interfered with, and in such a case the bark is as liable to attack as that of the heavily scraped trees.

During tapping operations the inner cortical tissues are opened up. In this connexion, the danger of bark affections similar to those observed in the experiment is slight. There is a considerable difference between exposing outer cortical tissues by scraping, and inner cortical tissues by paring, as in tapping. When tapping, the tissues down to the wood and bast-forming cambium are removed. Thus only very narrow strips of actively dividing cells are exposed at any one time. The coagulated latex along the tapping cuts protects these exposed strips to some extent, while the actively dividing cambium quickly cuts off layers of cells, one of which takes on the functions of a cork-forming cambium and the protective layer is soon replaced.

The selective nature of the borer attack was a noticeable feature. On Block I A, two days after scraping, signs of borers could be observed on every tree. Later the insects appeared to concentrate in a vigorous attack upon one tree. Such selection is difficult to explain, but is probably associated with the fact that plantation conditions are fundamentally unhealthy. Our conception of a healthy tree is limited by a spreading crown of leaves and roots apparently unattacked by disease. This gives no indication of one tree being more susceptible to disease than another, yet such is the case. Under forest conditions the struggle for existence operates in a drastic manner, and susceptible individuals seldom enter the competition. Plantation conditions considerably modify the struggle, and there must be large numbers of apparently healthy trees surviving which under natural conditions could never reach maturity.

Fickendy, in this application for patent rights, says that 'the bark should be scraped down to the cork-forming cambium; leaving the latter intact'. The experimental results show that the trees carefully treated as 
above may be attacked by borers and fungi, but that the susceptibility to attack is enormously increased if the cork-cambium is removed. The scraping of the bark so as to leave the cork-cambium intact, without exposing the outer cortical tissues, is a practical impossibility under estate conditions. This layer is very thin, and as the scraping would have to be performed by coolies, there is not the slightest doubt that large patches of the cork-forming layer 'would be removed. Such trees are comparable to the heavily scraped trees in the experiment.

It follows that bark-scraping of any description should be carried out with discretion. It is quite easy, with a little care, to scrape off the scaly bark on old trees without injury. This is done on large numbers of estates to ensure a clean yield of latex. It has been noticed on several estates that this has been undertaken so carelessly as to expose the outer cortical tissues, thereby laying the trees open to injury. Such carelessness must be severely condemned, and estates managers would be well repaid if they inspected scraped trees immediately after the scraping.

To all patent methods of increasing yield of latex there are serious objections. It is admitted by authorities that it is possible to exhaust a rubber tree by draining it too rapidly of its latex. This conclusion has been reached as a result of practical experience. Unfortunately there is little positive knowledge as to the function of latex in the economy of the tree, and until we gain more knowledge it is necessary to urge the desirability of a conservative attitude in connexion with methods for artificially increasing yield of latex. The problem to be solved is whether latex is a secondary waste product, the withdrawal of which from the laticiferous cells does not influence the vital processes, or whether it is a primary product, the withdrawal of which means increased activity on the part of the tree, in order to immediately replace that taken away. If the latter, then artificial methods of increasing yield beyond certain limits prejudices the health of the tree, while if it is waste material, any method of increasing yield might be employed, if the method of extraction, i. e. bark removal, \&c., did not interfere with the normal processes. In estate practice rapid removal of bark, which implies insufficient time for a good renewal, is the limiting factor in the tapping process, not the quantity of latex extracted. The problem stated above is of prime importance for the future of the rubber industry. The investigation of physiological problems has been neglected in the past, partly because of the difficulties which surround investigations of this description in tropical countries, and partly because more obvious matters demanded immediate attention. It is to be hoped that the line suggested will receive earlier attention, though many years must elapse before results of practical value are obtained. 


\section{$2 \mathrm{BHL}$ Biodiversity Heritage Library}

Sharples, A. 1918. "The laticiferous system of Hevea brasiliensis and its protective function." Annals of botany 32, 247-251.

https://doi.org/10.1093/oxfordjournals.aob.a089674.

View This Item Online: https://www.biodiversitylibrary.org/item/238284

DOI: https://doi.org/10.1093/oxfordjournals.aob.a089674

Permalink: https://www.biodiversitylibrary.org/partpdf/320217

\section{Holding Institution}

Smithsonian Libraries

\section{Sponsored by}

Biodiversity Heritage Library

\section{Copyright \& Reuse}

Copyright Status: Not in copyright. The BHL knows of no copyright restrictions on this item.

This document was created from content at the Biodiversity Heritage Library, the world's largest open access digital library for biodiversity literature and archives. Visit BHL at https://www.biodiversitylibrary.org. 